\title{
The Effect of Steroidal Extract of Nerium oleander on the Liver Tissue Structure of Albino Mice
}

\author{
Sahar A.A.Malik Al-Saadi, Karim H. Al- Derawi, Shiama Abd Alrasool \\ College of Science, Department of Biology, University of Basrah, Iraq \\ E. mail: Saharmalik2010@gmail.com
}

\begin{abstract}
Nerium oleander is an evergreen shrub of Apocynaceae family cultivated worldwide as an ornamental plant. All parts of the plant are toxic and contain a mixture of very toxic cardiac glycosides of cardenolides. albino mice were divided into four groups. group I was normal control group; and others represented three concentration from steroid component of Nerium oleander $(0.003,0.006$ and $0.012 \mathrm{mg} / \mathrm{kg})$. Liver marker enzymes were assayed in serum. Levels of marker enzymes such as alanine aminotransferase $(A L T)$ and aspartate aminotransferase (AST) were increased significantly. Sections of livers were observed under microscope for the histopathological changes such as destruction of the liver architecture with increased inflammation was observed compared with control.
\end{abstract}

Keywords: Nerium oleander, Leaves, Steroid extract, Toxicity, Mice.

\section{Introduction}

Nerium oleander (common oleander) is an evergreen shrub belongs to the family of Apocynaceae. It originates from the Mediterranean region and widely cultivated as an ornamental plant in many parts of the world, particularly in warm temperate and subtropical regions. This plant has long been known to be poisonous to animals and human beings. All parts of the plant are toxic and dry leaves are about as toxic as green ones (Kingsbury, 1964; Hardin and Arena, 1974; Zibbu and Batra2010).

There are large numbers of secondary metabolic compounds found in plantssuch as alkaloids, saponins, flavanoids and anthraquinones phytosterol. Parts of the plant can be ingested intentionally in suicidal attempts or accidentally. Following the ingestion of oleander, the clinical picture usually starts with gastrointestinal signs: vomiting, nausea, abdominal pain and diarrhea. Later cardiovascular and neurological symptoms can occur. (Goetz, 2005)reported thatOleander contains a mixture of cardenolides, the most important of which are oleandrin and oleandrigenin (Zibbu and Batra 2010). Oleandrin constitutes approximately $0.08 \%$ of the total content of cardenolides present in N.oleander (Marchioni and Distefano, 1989).

Nerium oleander as important plant used the leaves and the flowers are cardiotonic, diaphoretic, diuretic, anticancer, antifungal antibacterial (Abe and Yamauchi, 1992; Wang et al. 2000). This is a very poisonous plant, containing a powerful cardiac toxin and should only be used with extreme caution. The root is powerfully resolvent. Oil prepared from the root bark is used in the treatment of leprosy and skin diseases of a scaly nature. Plants have an extensive root system and are often used to stabilize soil in warmer areas. Seeds are Poisonous, abortifacient and alternative. They used as purgative in dropsy and rheumatism. The whole plant is said to have anticancer properties(Abe and Yamauchi, 1992; Wang et al. 2000; Zibbu and Batra 2010). For this purpose, we extraction of toxic components of N.oleanderspecialized steroids extraction

The aim of this research is to investigate and examine the hepatic histologist structure alterations and biochemical parameters that may be caused by administration of Nerium oleander leaf extract to albino mice.

\section{Leaf extract}

\section{Material and Methods}

Leaf samples of Nerium oleander were collected from University of Basrah from the garden, where the leaves are in fully green color. The leaves were thoroughly washed with water, dried and then ground with a blender. The powder (25) gm was extracted with methanol $90 \%$ The extract was with by using sexhlet aperture for $24 \mathrm{~h}$, the extract filtered and then dried.

\section{The animals}

A total number of 80 adult male albino mice were used in this research. The mice were in good health, approximately having the same weight $(30 \pm 5 \mathrm{gm})$ and 75 days in age. They were collected from Medical collegeBasrah University. They were housed in groups of 3 animals per cage at a temperature of $18-25 C^{\circ}$ under a $12 \mathrm{~h}$ dark-light cycle. The animals were left for one week before start of treatments. The animals were grouped into four groups each one is ten mice, the first one is control which was treated orally with distilled water, the second group 2,3,4: was treated orally using the stomach tube with $N$. oleander extract at dose of 
$0.003,0.006,0.012 \mathrm{gm} / \mathrm{kg}$ respectively. At the end of each treatment the animals were anaesthetized with diethyl ether, fixed the liver were taken for sectioning.

\section{Biochemical determination}

The biochemical parameters (serum enzymes): alanine aminotransferase (ALT) and aspartate aminotransferase (AST) and Alkaline phosphatase (ATP) were assayed spectrophotometrically using a commercially available assay kits according to the manufacturer's protocol.

\section{Preparation of tissues}

Tissue samples were fixed in equivalent formaldehyde solution $(10 \%)$, then washed with tap water. The samples were then dehydrated by being passed through serious of ethanol from $30 \%$ up to $100 \%$. Xylene was then applied for 30-40 minutes to clear the samples from ethanol. The tissues were subjected to paraffin infiltration using melted paraffin wax inside the oven at $60 \mathrm{C}^{\circ}$ for one hour.and the tissue samples were transferred from the oven inside these moulds which were then cooled to room temperature. The tissue sections were stained by using hematoxylin for one minute then in alcoholic eosen $1 \%$.

\section{Statistical analysis}

The data are expressed as mean \pm SD. Data were analyzed by analysis of variance (ANOVA) followed by multiple comparisons using SPSS test to compare all groups against control. Results were considered statistically significant at $\mathrm{p}<0.05$

\section{Results and Discussion}

\section{Biochemical parameters}

biochemical parameters studied were found to increase in the extracttreated mice at three doses as compared to the control mice. Values of AST (Aspartateaminotransferase), ALT (Alanin aminotransferase) and ALP (Alkaline phosphatase) significantlyincreased $(\mathrm{P}<0.05)$ by $126.50,95.67$ and $33.17 \%$ respectively in the mice treated with doses of $0.012 \mathrm{mg} / \mathrm{kg}$ body weight/day as compared to the controls. Such increases were insignificantwiththe $0.006 \mathrm{mg} / \mathrm{kg}$ body weight/day in ALP and AST stroidalextract treatment (Table 1).

Table 1. The Effect of the steroidal extract of Nerium oleander at doses of $0.003,0.006$ and $0.012 \mathrm{mg} / \mathrm{kg}$ body weight/day biochemical parameters.

*Values are mean \pm SEM.

\begin{tabular}{|r|r|r|r|}
\hline Treatment & ALP & AST & ALT \\
\hline Control & $85.17 \pm 1.17^{\mathbf{c}}$ & $24.50 \pm 2.06^{\mathbf{c}}$ & $24.83 \pm^{\mathrm{a}} 1.12$ \\
\hline 0.003 & $74.83 \pm 2.12^{\mathrm{e}}$ & $113.00 \pm 2.32^{\mathrm{b}}$ & $19.83 \pm 1.11^{\mathrm{a}}$ \\
\hline 0.006 & $88.00 \pm 2.40^{\mathrm{a}}$ & $88.17 \pm 22.14^{\mathrm{c}}$ & $20.00 \pm 1.33^{\mathrm{a}}$ \\
\hline 0.012 & $95.67 \pm 2.15^{\mathbf{b}}$ & $126.50 \pm 2.17^{\mathrm{a}}$ & $33.17 \pm 2.15^{\mathrm{a}}$ \\
\hline R.L.S.D. & 4.42 & 9.92 & 3.83 \\
\hline
\end{tabular}

\section{Histopathology of the liver}

Histopathological examinations of liver sections under light microscope revealed that there wereseveral changes in the mice treated with all doses of the steroidal extract as compared with thecontrol group. These changes include:congestion, inflammations around central vein in the $0.003 \mathrm{mg} / \mathrm{kg}$ bodyweight/day treated mice after two weeks ,as well as showed inflammations around portal triads, Kupffer cells appear after four weeks (Fig 1); cellular infiltrations and severe cytoplasm vacuolations(hydropic degenerations) of hepatocytes around central veins in which their nuclei were stainedpale and pushed to the periphery in the $0.012 \mathrm{mg} / \mathrm{kg}$ body weight/day steroidal extract treated mice, found necrosis and degenerations liver cells in addition inflammation of cells after four weeks, In addition, the mice treated with $0.012 \mathrm{mg} / \mathrm{kg}$ body weight/day showed congestion and degenerations liver cells and necrosis after four weeks from treatment.One of the mechanisms of plant extracts is the process of inhibiting the synthesis of purine and Alberuyemidn(Henghe Tian et al., 2007) 


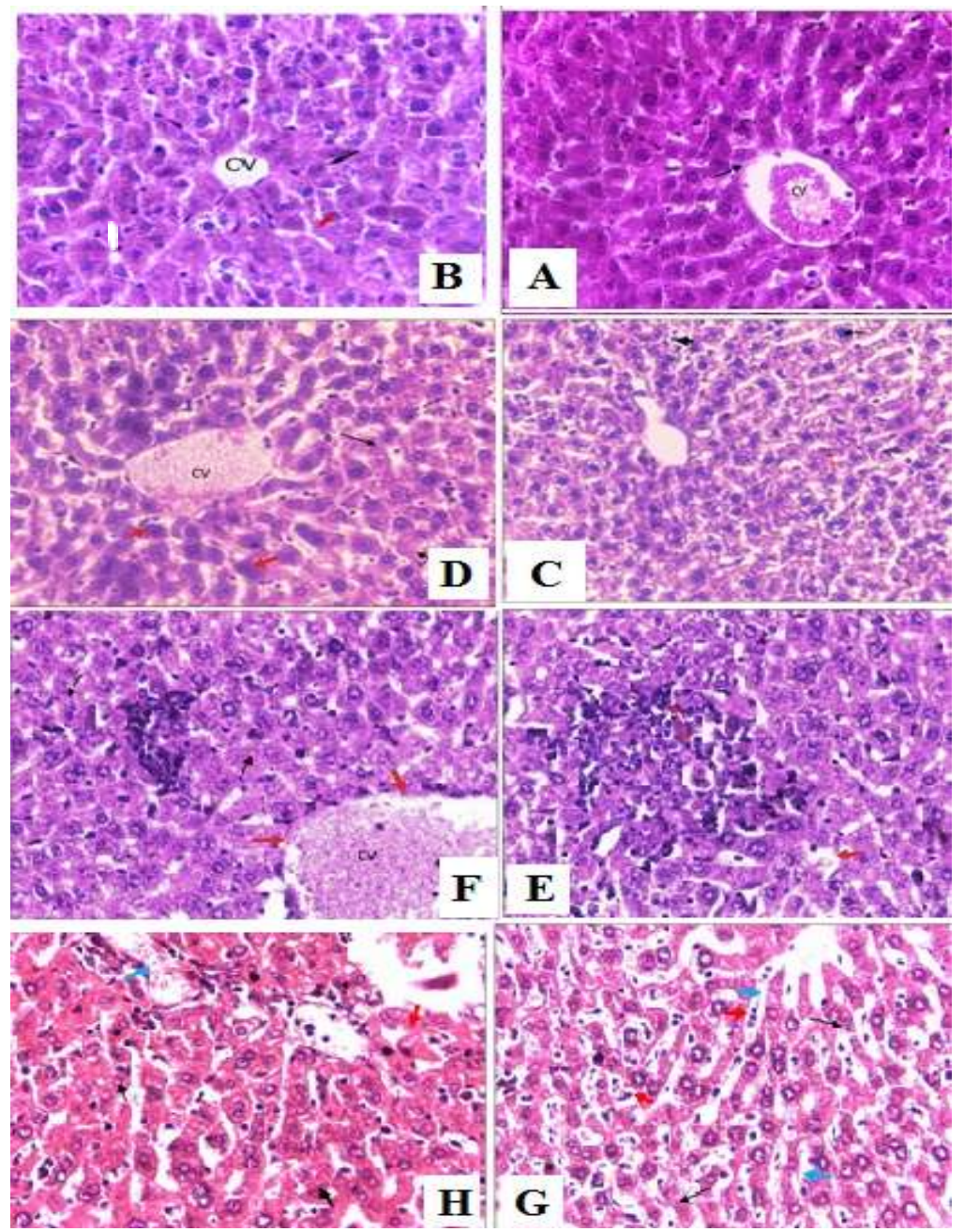

Figure -1: Photomicrographs of $\mathrm{H}$ and $\mathrm{E}$ stained liver sections from mice treated with Steroidal extracts of Nerium oleander at control mice (A) $0.003 \mathrm{mg} / \mathrm{kg}$ body weight/day showed congestion central vein and degeneration of endothelial cells after two weeks (B), $0.003 \mathrm{mg} / \mathrm{kg}$ body weight/day showed inflammations around portal triads, Kupffer cells appear after four weeks (C), $0.003 \mathrm{mg} / \mathrm{kg}$ body weight/day. Expanded central veins and The nuclei became Thickness of nuclei (D), aggregate ofinflammationsthicker, cells and sever hydropic degenerations (HD)(E), In $0.006 \mathrm{mg} / \mathrm{kg}$ body weight/day observed hydropic degenerations and haemorrhage $(\mathrm{F})$, while in $0.012 \mathrm{mg} / \mathrm{kg}$ weight/day found necrosis and degenerations liver cells in addition inflammation of cells after four weeks(G), In mice treated with $0.012 \mathrm{mg} / \mathrm{kg}$ body weight $/$ day showed congestion and degenerations liver cells and necrosis after four weeks from treatment $(\mathrm{H}) . \mathrm{CV}$ in $\mathrm{A}, \mathrm{B}, \mathrm{C}, \mathrm{D}, \mathrm{E}$, F G \& H = Central vein (Magnifications, all 450 X).Pyknotic nuclei

\section{Results and Discussion}

observed in the study, the steroidalextract compared with treatment control group showed an increase in the levels of ALT, AST and increasealkaline phosphatase levels in $0.012 \mathrm{mg} / \mathrm{kg}$ body weight/day usually increases remarkably in disease and lesser extent in hepatocellular diseases .The decrease observed in the increased levels of the enzymes AST,ALT, Alkaline phosphatase may be attributed to the protection offered by the administration of the steroidal extract of Nerium oleander. Many researcher reports the chemical component found in plant extract contain phytochemicals can interred with metabolism process and indicates the role of certain flavonoids, triterpenoids and steroids in hepatoprotection against hepatotoxins. The presence of those compounds in Nerium oleandermay be responsible for the protective effect on liver damage in mice.

The present study has found the presence of histopathological changes in the liver tissue of the different doses of extract treated mice. There were cytoplasmic vacuolations (Hydropic degenerations) in the hepatocytes located towards the periphery of the hepatic lobules around the central veins in higher doses of extract treated mice. This occur as a results accumulation of fluid or lipids as the result of disturbance in lipid inclusions and fat metabolism so that, cytoplasm becomes pale and swollen (Ebaid et al., 2007).

In conclusion, our results show that many effects of $\mathrm{N}$. oleander on liver and enzymes the hepatoprotective effects of may be due to its antioxidant and free radical scavenging properties. 


\section{References}

[1]. Abe, F. and Yamauchi. T. (1992). Phytochemistry 31 (7): pp. 2459-2463

[2]. Ebaid, H., Dkhil, M., Danfour, M., Tohamy, A \&Gabry, M. (2007). Piroxicam-induced Hepatic and Renal Histopathological Changes in Mice. Libyan Journal of Medicine, 2: 1-13.

[3]. Goetz, R. J. (2005). "Oleander" ( Indiana Plants Poisonous to Livestock and Pets. Cooperative Extension Service, Purdue University: pp.10-23.

[4]. Hardin, J.W. and Arena, J.M. (1974). Human poisoning from native and cultivated plants, 2nd ed. Kingsport, Tennessee, Duke University Press.

[5]. Kingsbury J.M. (1964). Hardin JW and Arena JM. (1974). .Poisonous plants of the United States and Canada. Englewood Cliffs, NJ Prentice Hall.

[6]. Marchioni, A.R. and Distefano F. (1989). Nerium oleander L. Le piantemedicinalidellaSardegna-Guidapratica per ilriconoscimento di 102 specie (in Italian).(Medicinal plants of Sardinia-practical guide-book for 102 species recognition). Ed.della Torre: pp.156157.

[7]. Wang, X.M.; Plomley, J.B.; Newman, R.A. and Cisneros, A: (2000). Anal. Chem. 72 : pp. 3547 - 3552.

[8]. Zibbu, G. and Batra, A.A. (2010). Review on Chemistry and Pharmacological activity of Nerium oleander L. J. Chem. Pharm. Res., 2(6):351-358 